\title{
Article \\ The Impact of Carsharing on Transport in the City. Case Study of Tri-City in Poland
}

\author{
Tomasz Neumann
}

check for

updates

Citation: Neumann, T. The Impact of Carsharing on Transport in the City. Case Study of Tri-City in Poland. Sustainability 2021, 13, 688. https://doi.org/10.3390/su13020688

Received: 22 December 2020 Accepted: 5 January 2021 Published: 12 January 2021

Publisher's Note: MDPI stays neutral with regard to jurisdictional clai$\mathrm{ms}$ in published maps and institutional affiliations.

Copyright: (C) 2021 by the author. Licensee MDPI, Basel, Switzerland. This article is an open access article distributed under the terms and conditions of the Creative Commons Attribution (CC BY) license (https:// creativecommons.org/licenses/by/ $4.0 /)$.
Department of Navigation, Gdynia Maritime University, 81-345 Gdynia, Poland; t.neumann@wn.umg.edu.pl

\begin{abstract}
The work on the impact of innovative solutions in urban transport on the inhabitants' quality of life was discussed. This paper presents the characteristics of the use of shared vehicles in the agglomeration, based on the example of the Tri-City. An analysis of vehicles' use in given periods of time was performed, indicating the growing interest in using this type of transport in the city. The work was divided into four chapters. The first part concerns the history of travel and urban development. The second discusses all currently available communication solutions in cities. The third chapter contains the research part. It focuses on presenting changes in vehicle availability over a more extended period. The fourth chapter describes the functioning of cars "for minutes" and the operation and use of dedicated mobile applications. The work ended with a summary of theoretical and cognitive content. A significant contribution is a brief analysis of the shared car market in the Tri-City. The available options are characterized. Also, the degree of use has been analyzed. The study concluded with theses about the further rapid development of this industry in northern Poland.
\end{abstract}

Keywords: transportation; car-sharing; carpooling; mobility

\section{Introduction}

Over half of the world's population are city dwellers. Many of them live in urban areas of millions. These robust "organisms" are becoming a challenge for designers, urban planners, logistics specialists, and local government officials. Considering the UN forecasts, which project the city's population to reach 6.3 billion ( $72 \%$ of the Earth's population) by 2050, we now need to change the way we think about their functioning. According to the concept of sustainable development, it is necessary not only to ensure "meeting the needs of present generations but also to consider future ones" [1].

Future mobility is a pervasive theme-a development that is still in its fledgling stage and has not yet reached its peak by a long way. Mega-trends, technology-led innovation, and regulatory conditions change the nature of mobility as the sharing economy is approaching. Car sharing is a critical aspect of itself, and the market is committed to offering personal convenience and social improvement [2,3].

One of the fundamental problems of a modern city is to organize the transport of people and cargo so that it does not burden the inhabitants and the environment. Current urbanization processes reduce the quality of life [4]. Today, many Polish cities are crowded and overpopulated. There are countless vehicles of all kinds on the roads: from small twowheelers such as bicycles or scooters, through passenger cars and small delivery vehicles to large trucks and lorries. The Statistics Poland report states that in 2017: 29,634,928, 2018: 30,800,790, and 2019: 31,989,313 motor vehicles drove on Polish roads, including 2017: 22,503,579, 2018: 23,429,016, and 2019: 24,360,166 passenger cars (49\% more than ten years earlier) [5]. The ever-increasing number of motor vehicles means environmental degradation. In terms of air pollution, Polish cities are infamously leading the way in Europe. The level of street noise is also high. All this means that Poles are increasingly affected by numerous civilization diseases. The increased traffic of cars is also one more 
dangerous danger: in those mentioned above in 2017, 23,262 accidents occurred in built-up areas, in which 1238 people were killed, and 267 people were killed at pedestrian crossings. You can't ignore such statistics.

Moving is a necessity to cover long distances, traffic jams, looking for parking spaces. It all limits the time to rest, intensify stress and tension. The signatories of the Lisbon Charter pointed this out: they said that now we need to look for solutions to problems that may arise in the future. In the document, they wrote:

"The growing need to create an urban environment which, apart from health and peace, gives a high quality of life, makes an important challenge for cities to shape their future in a way that ensures balance and harmony between social, economic, and environmental aspects of development" [6].

Bold thinking is necessary. Not too long ago, some ideas would be considered technical experiments that could not be used on a large scale, as fantasies and trivia. The rapidly changing reality requires bold visions. This also applies to transport and its infrastructure, i.e., the fields that are the subject of this work. There are many indications that to improve urban residents' quality of life, the number of cars needs to be severely reduced. This can be done innovatively, using available transport solutions [7]. This work attempts to approximate the solutions functioning in Poland and the world and show why they are prospective and how they can affect urban residents' health and their safety on the roads. An analysis will be presented regarding the frequency of the Traficar car-sharing system by residents of the Tri-City, available in the Metropolitan Area's streets from November 2017.

Due to the not-so-long operation of the said solution in Poland, and even shorter in the Tri-City (which will be most affected by this work), there are not too many studies on this topic. Many materials, especially those regarding car sharing, carpooling, ridesharing, etc., can be found mainly in articles and blogs on the Internet [8]. The number and variety of ideas for improving communication in densely built-up and often overcrowded cities make this topic very extensive. Therefore, some issues will only be discussed briefly.

The paper aims to present changes in modern society in terms of city transport. The second goal, but no less significant, is to provide an analysis of the use of carsharing in the Tri-City. In line with the global trend, owning a private car is not unusual. Driving this car through the crowded streets of large cities is a challenge. Too many vehicles make it much more difficult. The article presents changes taking place in the Tri-City in Poland, analyzes the short-term rental market, and puts forward conclusions regarding this solution's future.

\section{Need for New Ways to Use Available Means of Transport}

The modern city is a very complex organism that can be studied and described in many ways. Its researchers include urban planners, sociologists, lawyers, geographers and economists, and logistics specialists. Each of these specialists defines the city differently and takes into account different aspects. In the book [1], we find a definition in terms of logistics, according to which the town is: "The area in which the principles of logistics management and system thinking should be applied to improve and increase the level and quality of life of residents. Identifying logistic streams and the problems they cause requires finding ways to relieve cities of the adverse effects of modern business operations and increase a given area's economic competitiveness."

The same author presents the city as an administrative unit: "A city is a unit with municipal rights, formally an administrative area, with statistical demarcations, it is a relatively closed area with a high population density" [1].

Of course, modern cities from the beginning of the 21st century in many respects differ significantly from urban centers from previous centuries, most from the oldest ones, whose creation dates back to the second half of the sixth millennium BC. First, people lived in smaller clusters - in the villages. They arose when a man began farming, which forced him to settle down. Later, craft and trade developed, settlements grew, and the inhabitants' new needs appeared [9]. In various historical periods, economic formations, and geographical regions of the city, they differed in functions, size, and form. 
As the number of inhabitants and the diversity of their jobs increased, new networks of social, economic, and cultural interrelationships and relationships emerged [10]. The use of shared infrastructure and participation in collective undertakings required creating legal regulations and establishing various units managing a given community [11,12]. Such communities could function well when everyone accepted the rules and followed them: the larger the community, the more complex the organization of its life.

Inhabitants of large cities have always had their specific problems, for example, access to water, disposal of dirt, or narrow streets hindering movement. Clamping and crowding, combined with poor living conditions, have often resulted in epidemics, fires, and unrest. The era of cities began in the second half of the 18th century with the industrial revolution. Numerous technical inventions and scientific discoveries influenced various goods, which started to migrate from the rural population to cities. A century later, in 1851, for the first time in history, a census in Britain showed that more Britons live in the towns than in the countryside. New cities have become influential construction sites. Not only were houses built, but also railways, bridges, and even metro lines. However, with the advent of cars, care was taken to ensure suitable road surfaces.

Each year brought discoveries and different technical solutions. Some cities grew at a rapid pace. Hurry meant that ad-hoc solutions that did not take into account aesthetics or functionality were often chosen. It has not always been associated with aesthetics and functionality. In 1933, the International Congress of Modern Architecture (Congres International d'Architecture Moderne, CIAM) created a unique document called the Charter of Athens, which appealed to design cities in a way that would serve people. The authors of the Charter concluded that a person needs: housing, work, and places that allow spending free time (recreation). These three zones must, of course, be combined into an efficient traffic system.

To this day, it is recognized that the Athens Charter is the essential urban manifesto of the twentieth century, which everyone should know, having an impact on shaping current cities. Not all communication solutions proposed in this text were accurate, but it certainly taught a modern perspective looking at problems. "If it weren't for Kart, everyone would be living in an impenetrable crowd, nobody could get anywhere, because the tangled streets would not be straightened, the nearest forest or a larger park would be beyond the reach of an ordinary inhabitant".

Another document from 2003 referred to the Athens Charter-the New Athens Charter. The vision of the 21st-century cities also called the Lisbon Charter. It contains a diagnosis regarding communication in modern cities:

The development of transport infrastructure, ensuring better accessibility of land, creates at the same time new barriers and obstacles, especially for pedestrian traffic and slower means of transport. As a result, the dominant spatial structure divides and breaks down individual urban units and landscape systems. Suburbanization and the spread of urban functions towards the periphery leads to longer vehicle paths and, as a result, to a deterioration in the quality of service and services. An additional problem of cities is the decrease in the number of passengers in public transport and increased private vehicles' use.

Contemporary urban centers are changing even faster than in previous centuries. During rush hours you have to transport thousands or even millions of people. Logistics and designers face limited road capacity, and public transport is crowded to the limit. How to meet the needs of moving residents in such a situation? For many people, two, three, four hours spent on buses, trams, trains, or the subway are commonplace. After all, it is necessary to reach a distant school, workplace, office, and medical visit for a specified hour. As cities grow and more and more often escapes to their outskirts or suburbs in search of cheaper apartments, a quieter neighborhood, and a cleaner environment, distances increase.

In 2007, ministers of European countries announced the Leipzig Charter on Sustainable European Cities. She points out that: "Sustainable, easily accessible, and cost-effective urban transport systems with pooled connections to urban transport systems are an essen- 
tial factor in improving the quality of life as well as local conditions and the environment. Here, special attention should be given to managing traffic and connecting transport media, including cycling and Urban transport, to adapt to the functional requirements of individual urban areas: jobs, housing, the environment, and public spaces." [13].

The city space is a place where different interests intersect. Permanent residents expect low noise levels and limited pollution, which are, among others, the effect of minimized car traffic. Still, in addition to permanently registered residents, many newcomers arrive for specific purposes. A large city is often an administrative center where important offices, offices, courts, medical facilities, and universities are located. A person from the outside needs good signage and information, available parking spaces, convenient access (beltway). He also expects clear, precisely described transport connections when he decides to use public transport. In cities eagerly visited by tourists, apart from transparent information, what counts is the possibility of quick calculation of travel costs. Reasonable solutions can be reached by trial and error, but it is increasingly common for cities to form relationships or communities and share experiences [14]. The agreements concern shared information networks and such solutions as several-day public transport tickets, which are valid in several cities, and is accompanied by an offer of journeys, e.g., by train between associated towns [9,15].

For some time now, the intensification of works related to the introduction and use of new transport systems in cities has been noticeable in most countries. Transport in urban agglomerations creates well-known difficulties. Apart from the aforementioned low road capacity, causing traffic congestion (traffic jams), the high collision should be mentioned, especially among cars, their high energy consumption and carbon dioxide emissions causing environmental pollution. Designers and builders face significant challenges, descending underground with subway lines or underground parking lots or erecting viaducts and cleverly resolved intersections to create collision-free connections. All these solutions are costly, but they must be to meet the security requirements. Moreover, threats can come from people (terrorism) and be the result of natural disasters [16].

\subsection{Demand for "New" Means of Transport}

People have moved since the earliest times. They were forced to do so by depletion of natural resources, climate change, or killing animals. They set off on a journey in search of new hunting grounds and arable land. Everything began to change when the first permanent shelters were built and the first settlements were created. The first trade routes were made; the roads were used more often [17]. At the very beginning, people were walking. Thanks to animals' domestication, man began to use draft animals: horses, donkeys, camels. This allowed for a significant reduction in travel time. After the wheel's invention, various vehicles began to be built, ranging from simple wooden trolleys, through war chariots, to animal-drawn carts of different types and purposes. With the development of technology, industrial and progressive revolution, the quality of transport has improved [18].

You have always traveled and still travel for a variety of purposes. Usually, the essential factor in choosing a means of transport is moving from point A to point B. Sometimes, the choice depends on comfort and convenience, the amount of space available, or the covered distance.

The car caused a real revolution in the development of transport. If it did not appear in the nineteenth century, there would be no discussion about public transport and the necessary directions for its changes. Two centuries ago, no one could predict to what extent motor vehicles would overrun public space. The appearance of modern cities results from many urban decisions taken at a rapidly increasing number of cars. They had and have an impact on the functioning of cities and their structure [9].

In the first decades of automotive development, it was noticed that the systematically increasing number of cars generates numerous problems. The first road accidents involving pedestrians and drivers were a shock. Streets became dangerous, and regulations were quickly created to ensure the safety of all road users [19]. 
Congestion, i.e., congestion, has become another troublesome phenomenon related to the growing number of vehicles, especially during rush hour. Traffic jams apply to every city, both large agglomerations and smaller towns, as well as all types of cars. Nobody can avoid them. Driving time increases. It is difficult to rationally use it, so drivers' stress and aggression increase, delivery is delayed, and entrepreneurs' costs increase. In the case of public transport, to implement the number of routes envisaged in the timetables, the number of vehicles must be increased, which results in further expenses.

One of the reasons for increasing the number of cars is also settling in the suburbs. Urban development caused a significant increase in population and a constant demand for housing. Real estate prices outside of the centers encourage people to settle there. Simultaneously, the distance between the apartment and the center is lengthening. Because the ample space is best covered by your car, the number of passenger cars within cities has increased. This, in turn, became the cause of traffic jams from suburbs and suburban towns. As it turns out, transport is one of the critical systems affecting cities' functioning and structure.

Today, almost everyone wants to own a car. Fears that were widely discussed at the beginning of the motoring industry have long since been dispelled when it came to safety, appearance, loud engine operation, or fuel availability (gasoline could only be bought at pharmacies) [20]. Once, few people owned private cars because they were expensive, so they testified to the owner's wealth and added prestige. At present, in many societies, the possession of at least one car by a household is becoming the norm. The variety of brands, equipment versions, paint colors, and body types allows the model to be adapted to the owner's needs. In such a situation, it is difficult to imagine introducing administrative restrictions on passenger cars' possession or use. At the same time, there is a growing awareness that there are too many of them, and it is necessary to encourage the use of other means of transport. After a thorough analysis, one can conclude that the car is not always the most practical means of transportation.

\subsection{Advantages and Disadvantages of Having a Private Car}

The most important advantage of your vehicle is that it allows passengers and goods to be moved in a door-to-door relationship. However, its attractiveness decreases significantly when roads get jammed, and you have to, despite the vehicle's capabilities, move forward very slowly [21].

What are other reasons for choosing your car instead of a streetcar or city bus?

- Climate. A car protects against the vagaries of weather: at any time of the year, the traveler finds shelter in it against rain, wind, or heat.

- $\quad$ Convenience. You can put your luggage in carefully and slowly (It will not go away!) and arrange them so that they will not be damaged. Moreover, it is the driver who decides what traveling companions he will have- he is not, as in the means of mass communication, dependent on noisy, aggressive people, and the crowd on a tram or bus, and always has a seating position, which is especially important for older people, sick or with young children [22].

- Availability. Buses, trams, queues, and the subway run according to the timetable. It is not possible to adapt journeys to the needs of passengers: neither delay nor accelerate. An additional problem can also be too few courses, while passengers often have to count on themselves in the event of a breakdown.

- Travel time. The average journey time in comparable conditions by public transport and your car is much shorter when you drive.

- Security. By driving your car late in the evening or moving in poorly lit areas and in areas where many crimes are noted, the driver and passengers can avoid assault, theft, or beating. Traveling by public transport does not provide such protection.

Owning a car gives the driver high independence. He usually uses it for private purposes-from taking children to the nursery, kindergarten, or school in the morning, commuting to family trips, etc. He often uses the car as an office or as his work tool 
(e.g., if he works as a sales representative). Drivers do not limit any timetables, lack of space in the middle of the vehicle in the traffic peak. He can choose the route himself, correct it at any time or change it, stop, take a break, get off, switch with another driver, set the temperature or music that suits him [23].

To the cited arguments deciding about the desire to have a private vehicle, one more must be added: in Poland, over the past 20 years, the car has become affordable for average earners. Since the import of used vehicles from Western European countries, their prices have dropped significantly. The cheapest can be bought for several hundred PLN.

The advantages of having your car are many. On the other hand, the disadvantages of this situation should be cited. Buying a car is just the beginning of the investment. There are also fixed costs of use and maintenance. The largest is currently associated with very high fuel prices-both gasoline and diesel. Much also depends on the age of the vehicle and its failure rate. The older the car, the greater the costs associated with repairing the car and replacing parts. You can't forget about insurance and technical inspections $[24,25]$. It is also supplemented with various operating fluids (e.g., coolant or washer fluid).

A private car owner needs a permanent parking space as close to home as possible, preferably in a garage or underground parking. Covered rooms protect against damage, corrosion, dirt and make you independent of changing weather conditions: the driver does not have to worry about scrubbing frozen windows and removing snow from the car. It is also calmer that no one will scratch the paint maliciously at him, and above all, the vehicle will not be stolen. Of course, you have to pay for the luxury of garage parking, and finding a garage in some areas of the city, such as where old buildings dominate, is not easy.

Finding a parking space near work, offices, hospitals, shops, and recreation places during sporting or artistic events, mainly when they occur in densely built-up districts without modern infrastructure, is another challenge in a contemporary city. Going to a theater performance or an appointment with a doctor must provide time to find a car park and free space. Further, parking in city centers is increasingly associated with additional charges. These are the reasons for using the car.

\subsection{Alternative Solutions}

The awareness that there are too many cars around us is becoming increasingly common. The question arises on how to move around large urban spaces, giving up driving your vehicle. Alternative solutions are the answer: some are already quite popular, others are at the experimentation stage. Various systems for individual road users: car drivers, motorcyclists, scooter drivers, cyclists, and pedestrians are considered and implemented more often in cities. From traditional taxis, through private Uber, Taxify, to car-sharing systems emerging massively in Poland in recent years, following the example of Western European countries, and "shared" two-wheelers-scooters, bicycles, and even ideas for the dissemination of electric city scooters that have been recently considered and introduced.

Bicycle fashion has returned for some time now. Much cheaper to buy and maintain than a car, and smaller and easier to store (all you need is a balcony, basement or bicycle parking inside a closed housing estate), so more and more people choose this vehicle as a means of transport [26]. It allows transporting goods and purchases, and above all is a form of physical activity that greatly affects the condition. The fashion for these two-wheelers is strongly supported by health campaigns and advertising, in which fit and satisfied cyclists appear. Such communication does not burden the environment and is energy-saving.

However, for cycling to become commonplace, specially tailored routes and paths are needed. Traffic in cities is so high that driving on car lanes is too risky. It may cause accidents. In our climatic conditions, a bicycle cannot be a year-round means of transport. Snowy and icy routes are dangerous. Another threat for two-wheelers is smog. In some periods, inhaled air is so polluted that it becomes harmful [27].

The city bike rental system, which works in many cities, also encourages to change a car for a bike [28]. The low subscription cost and free use of the system, even for tens of 
minutes during the day, is very convenient. The user is also released from concern for the technical condition of the vehicle and its storage.

Another alternative is the different forms of car sharing-from group commuting to the university among friends through journeys from one city to another with a driver found through an internet portal or smartphone application (carpooling), to the shared use of so-called "cars for minutes "in larger cities (car-sharing).

A very interesting concept combining individual transport with public transport is P\&R's construction (Park \& Ride-park and ride) and B\&R (Bike \& Ride) interchanges. It is assumed that parking lots will be created near the stops (point infrastructure), where travelers will leave private vehicles and change to public transport. The incentive to use this solution must be both the appropriate number and capacity of parking lots and adapting to the needs of the number of public transport vehicle routes and their reliability. Cars left in parking lots mean environmental protection, less crowded streets, and, therefore, more safety in them.

The proposed concepts of multimodal communication should go hand in hand with the introduction of an electronic ticket, which will also be a parking ticket at the P\&R stop and a public transport ticket.

For such solutions to be adopted, city managers must educate the community, carry out promotional activities, and above all, take care of the logistics of projects-additional infrastructure (bicycle paths and parking lots) and efficient public transport. It is an ideal solution, especially for suburbs and districts distant from the center and for visitors. These concepts should be combined with limiting the number of parking spaces in the center and increasing the fees for leaving vehicles in these car parks.

The B\&R concept assumes that you can move around the city by bicycle, which is transported without public transport problems. This is an additional argument in favor of riding bicycles in the city [29].

\section{Innovative Use of Communicated Transport Means}

After considering the pros and cons of moving in urban areas by car, bicycle and public transport, one should look at innovative ways of using transport means to positively improve the quality of life in the city.

\subsection{Carsharing}

Carsharing is one of the forms of shared use of a passenger car. The idea of this system is the possibility of short car rentals to move within the agglomeration. The travel costs are quite high, especially concerning public transport journeys. Carsharing is also the maximum simplification of procedures that would appear when using the rental company. The intention to rent a vehicle is enough to report via the Internet, phone, or mobile application, while specially prepared cars are waiting for customers in designated places $[30,31]$. Carsharing can also be the use of one car for a longer period (following the principle of shared costs). Anyone with a driving license can be a participant in such a system.

In the 1980s and 1990s, small companies offering car-sharing services began to appear in the European countries - in Switzerland, Germany, Sweden, The Netherlands, and North America in Canada and the USA. For the first time, the idea of short rentals "for an hour" of specially designed cars began to be implemented. Very often, such undertakings were co-financed from public funds. However, these were just shy beginnings, market recognition. At the same time, the 21st century is a real-time of car-sharing development. In the USA, companies like Zipcar and CarClub were founded in 2000. Thanks to them, the popularization of car-sharing gained pace. In 2012, car-sharing services were already available in 27 countries; around 1.7 million users used them. Currently, world leaders in car-sharing are Zipcar and Autolib.

The rapid entry of car-sharing onto the market was not missed by other players operating on the transport services market. Car rental companies reacted the fastest to this 
phenomenon, and the first car-sharing services began to offer it already in 2008. They were, among others: Hertz on Demand, WeCar, and Uhaul Car Share or Avis On Location. Big car companies also followed car rental companies. Seeing the interest of young drivers in using good cars for a reasonable price and thinking about the attachment of future customers to the brand, they began to follow the trend.

The largest car-sharing service globally is Car2Go, a brand created in 2008 by Daimler. This service is currently available in 30 cities worldwide: it is used by about 2 million customers who have over 14,000 at their disposal cars. BMW (DriveNow), Volkswagen (Quicar service-owned by Greenwheels since 2006), General Motors (Maven service, which also accepts small orders), Citroën (Multicity service), and Mercedes (Croove service) also have their car sharing websites.

Poland is not far behind the western market. Car sharing services are being introduced consistently in larger Polish cities, and their number is increasing from month to month. Cars can be used "in minutes" in many cities, there are the following companies:

- Traficar-Kraków, Warsaw, Wrocław, Poznań, Tricity, Silesia.

- TrafiCargo-Kraków, Warsaw, Gdańsk, Poznań, Wrocław, Katowice, Rumia, Wołomindepending on the city, cars can be rented at selected IKEA construction stores, Castorama, Leroy Merlin.

- CityBee-Warsaw, Kraków, Wrocław, Tricity, Katowice, Łódź, Poznań, Białystok, Bydgoszcz, Lublin, Szczecin.

- EasyMotion-Poznań.

- 4Mobility-Warsaw, Poznań.

- GoGet-Wrocław.

- EMobility-Gdańsk.

- MiiMove-Tricity.

- Vozilla-Wrocław (electric cars).

Polish car-sharing services use developed foreign designs, although they make other car brands available, and the charging system and rates are adapted to our conditions.

Magdalena Hibner, Marketing Manager at Traficar, provides statistical results that show the extent of interest in Polish car-sharing drivers: "within half a year of launching the service, 8000 users used the fleet. All cars traveled over 400,000 km during this time. Statistics show that they travel most often with shopping and university faculties. The course's average duration is about $30 \mathrm{~min}$, although with month by month is changing dynamically. We also observe that customers are more and more enthusiastically using the so-called parking fee, which is $\$ 0.10$ per minute (easy conversion: P.L.N. 6 per hour)."

What is primarily associated with car-sharing? It is a service that leaves the driver a lot of freedom, even though the vehicle is shared. The rented car is used for exactly as much time as is needed and on the route that interests the driver (in the case of ridesharing, e.g., BlaBlaCar, the driver determines the way, the passenger usually has no influence on it). The significant advantage is the possibility of leaving the vehicle parked for a while without the need to re-order transport (as in the case of ride-sourcing, i.e., services such as Uber and Lyft).

The main advantage that distinguishes car-sharing from traditional car rental and leasing is attractive cost reduction. You pay for the distance traveled, while the rental companies have a specific daily rate. The car-sharing fee automatically includes fuel and insurance costs. If, while driving, you find that there is not enough fuel to continue driving, companies allow you to refuel the vehicle at their own expense. Of course, after presenting the receipt, all costs will be refunded. In some companies, a fuel card is assigned to each vehicle, for which the user gets special discounts for subsequent journeys [32].

When parking in the city's paid parking zone, the user does not have to worry about additional charges-they are already included in the rates for using the car (Traficar). The exceptions are zones separated by a resolution of the city authorities (e.g., only for emergency vehicles) and in places allowed for parking only at certain times. 
When parking the car, the users of the service have certain rules: you cannot leave your car in a private car park (for example, at shops or shopping malls-from where it is not always possible to go and where, due to the length of the car park, locating the vehicle can be very difficult). The user who left the car in an unauthorized place pays for parking or hauling the car from a place where the vehicle should not be rented. Of course, all fines are placed on the user who committed the offense [33].

What are the advantages of using the car without owning it? There are many of them, and the most important of them are economy, ease of renting, "uncorking" cities and parking spaces and reducing pollution levels.

- $\quad$ Savings - the borrower pays a very small fee. Due to the car's short-term use, prices may be only a few zlotys (minute, hourly charges). Moreover, you save on a very low, and often zero parking fee.

- Low degree of formalization and complications - the car rental process is carried out through the application and is mostly automated.

- "Uncorking" the city and parking spaces-in cities where car-sharing services operate, the number of vehicles traveling on the road decreases. One shared car reduces traffic and saves a lot of valuable parking spaces in city centers. A rental car can replace 8-20 private cars during the day.

- Reduction of pollution levels-fewer vehicles means fewer exhaust gases and noise (also treated as pollution). Carsharing also speaks in favor of the fact that Polish fleets have available combustion cars that meet the European emission standard (Euro 6) or electric cars.

However, it should be remembered that, like any car-sharing system, it also has disadvantages. Currently, the main problem is not enough vehicles available. This means that this service user cannot be $100 \%$ sure that he will use it. Car sharing service providers are aware of this inconvenience, so they are continually increasing their fleets in response to ever-increasing demand.

Another problem associated with this is that most car-sharing operators provide their services only in one city. This makes it difficult to make a longer trip beyond its borders (usually, the car should be left in the city where it was rented). An additional problem may be the limited range of electric vehicles, which in countries with infrastructure not adapted to their needs (like Poland) may have difficulties in covering long distances [34].

International statistics strongly speak in favor of car-sharing services: a 2015 Frost \& Sullivan report states that around 7.9 million people have already used these services worldwide. The number of vehicles available to users was 112,000 . It is estimated that the upward trend will continue. It is estimated that in 2025 car-sharing may have as many as 36 million users who will use 427,000 vehicles. At the same time, BCG (Boston Consulting Group) estimates that by 2021 the number of cars sold per year may decrease by 792 thousand! This is due to the growing popularity of car-sharing in America, Europe, and Asia.

When reducing the number of passenger cars in increasingly populated and polluted cities becomes a necessity, car-sharing and other solutions in the sharing economy seem to be the future of transport. This is facilitated by a change in ownership among representatives of the young generation, whose representatives value practical considerations more than the prestige associated with ownership. All this means that more and more cities in the long-term development strategies include introducing this service type. Simultaneously, local government officials support the idea of shared travel, discouraging residents from using their cars in city centers. They do this by introducing high parking fees, a high degree of formalization, and the costs associated with registering new vehicles.

Where residents are not yet aware that this is a beneficial communication solution, local authorities must create a friendly climate around car sharing. This is done in many ways around the world:

- commissioning research that predicts the success of car-sharing services among the inhabitants of a given city, 
- incorporating car-sharing into the city's long-term communication strategy, e.g., planning and separating special parking zones for rented vehicles and enabling bus lanes, etc.

- reducing the costs of service operators, e.g., by reducing parking fees or offering free parking,

- cooperation and consultation with cities that use car sharing,

- running car-sharing programs for municipal employees (e.g., a collaboration between Houston and Zipcar).

In recent years, communities and self-government, which care about improving the quality of life in cities, are also becoming active in Poland. Looking at good models, they strive to introduce them to us and lobby for traffic reduction.

Urban car-sharing is overgrowing in Poland, which will probably soon make it take a strong position in the sharing economy's domestic landscape. Free travel to work with a rented car in large Polish cities ceased to be something special. Now and then, new service providers appear, and companies that already operate on the market are expanding their services beyond one city while expanding the fleet.

Car sharing services still need good regulation. The President of the Management Board, Traficar pointed out: "There is currently no legal regulation for car-sharing services providers. Cities are currently using a tender tool due to which one winning company is to receive a privileged position, e.g., access to bus lanes. In our opinion, the optimal solution would be to create provisions at the level of the national act or within the competence of local governments offering support to the entire category, and therefore all companies that offer car-sharing services. Co-financing is more justified in the case of public transport (including bicycles) than renting a car" [32].

\subsection{Carpooling}

It has long been noted that traveling by individual people by car is very uneconomical. The consequence of this was the introduction of a system called carpooling in the mid1970s. It consists of making available to travelers places in private or business cars. In the beginning, the system appeared where there was no public transport due to the low traffic volume [35,36].

People who plan to travel in their car, offer free seats on a specific day and time. Information reaches through the websites to those interested in using this proposal because carpooling is based on the database of people traveling. The most known databases in Poland are websites, such as www.carpool24.pl [37], www.blablacar.pl [38]. In addition to services, proposals are delivered via social networking sites, mobile applications, discussion forums, and even posted on bulletin boards, offices, or universities [39].

The basis of carpooling is the agreement between system users, i.e., between the car owner as a lender of space in his vehicle and passengers reporting the desire to use this space. By participating in organized travel, travelers can benefit primarily from shared costs. The lender of space in his car has a passenger-compensated part of the vehicle's operating costs, saving money because he would have to pay more when driving his car or taxi. In some cases, it is also cheaper than tickets on public transport. This system is prevalent in the United States, while in Europe, it is less popularized.

Carpooling is one of the concepts of integrating collective transport with an individual. Users of it decide to limit the number of vehicles driving on city streets. Sometimes, four people's travel in this system means leaving as many as three vehicles in the garage. This is especially important during the morning and afternoon rush hours. This way of traveling suits people who are open to new acquaintances and are curious about the world.

The concept of carpooling means reducing travel costs (including fuel, vehicle depreciation) and reducing congestion during rush hour. Local authorities should encourage joint travels in cities, including creating several privileges for owners of vehicles taking an active part in carpooling (based on issued cards). Such requests include discounts on parking fees, co-financing of motor insurance, etc. Moreover, carpooling in Poland needs a strong promotional campaign. 
Carpooling, like any other transport system, has its advantages and disadvantages. The benefits are related to three groups: users, the local community, and institutions supporting the organization of carpooling. Users choosing this form of movement spend less on journeys, without sacrificing the convenience of driving a car than public transport. The local community will benefit significantly from reducing air pollution and environmental degradation, and congestion on the roads. On the other hand, institutions whose employees use carpooling can count on greater employee integration and better public perception of the company. In addition, carpooling means the end of problems with congestion of company car parks.

For passengers and drivers, shorter travel time is also important when vehicles with many passengers have separate HOV (High Occupancy Vehicle) lanes on a given route. Everyone but the driver can devote this shortened driving time to integration and work-to review notes, check information, etc.

As for the disadvantages of this system, for users, it can be embarrassing surprises such as traveling with an arduous passenger (a capricious little child or animals), as well as the risk of getting on a not very polite driver who counts primarily on earnings, and inaccurately meets the agreement. Driving your car, you can do many other things "on the way", arriving in several places. The carpooling driver takes us to the site. The car planning owner, to lend it to others, must determine the time and place of pickup of passengers, which sometimes will require making the route, leaving home early, and returning later. Moreover, you always have to take into account the risk of damage or soiling of the vehicle.

\subsection{City Bicycles}

A healthy lifestyle is promoted in many cities around the world, including Poland. A great way to improve the physical condition is riding city bikes for recreational purposes and on the way to work and school and even shopping. A well-developed bicycle network allows cheap and healthy travel in crowded parts of cities and on their outskirts. Twowheeler rental is usually possible $24 \mathrm{~h}$ a day, every day. Some systems operate yearround, others from the beginning of spring (March, April) to the end of autumn (October, November). The main idea of introducing systems that offer city bike rental is to reduce congestion on roads and improve health and increase urban residents' physical activity.

The originator of the idea of city bike rentals was the Dutch anarchist Luud Schimmelpennink. His project assumed that the center of Amsterdam would be closed to car traffic, and at the same time, the city would buy twenty thousand bicycles, which are public property and accessible to everyone. In 1965, together with friends from the Provo movement, they collected dozens of bikes, painted them white, and set up in Amsterdam for free use. However, they were requisitioned by police on the basis of a provision that prohibited unsecured bicycles in public places.

Fortunately, this did not discourage cycling enthusiasts, and similar projects began to appear in more and more cities. For example, in 1974, the French town of La Rochelle opened a public bicycle rental modeled on the proviso model. The "Yellow Bicycle", which was launched there and in Portland, America, was the most successful [20]. The first network of large-scale public bicycles rented on bail was launched in 1995 in Copenhagen. The system was called Bycyklen and had 2000 bikes and 110 bikes pick up and return stations. The vehicle was picked up by placing a coin-deposit in a special slot. Attention was also paid to ensuring that bicycles are adapted to intensive use. It was supposed to protect them against theft by the originality of parts that could not be installed on other bicycle models. Despite this protection, bikes were often stolen because their users remained anonymous. It wasn't until the introduction of the bike about the system at Portsmouth University in the UK that a way of protection against theft was found. Students had to obtain a magnetic card that could be used to track the bicycle journey. This innovation was named the third generation of the PBS (Public Bike System). In subsequent years, new networks appeared introducing new technologies in technology, such as the possibility of paying for the service by telephone or multifunction cards, and even security chains stand 
with electronic locks and on-board computers. With the Velib' system, Paris has certainly become an example of perfect implementation of the PBS It has over 20 thousand bicycles at over 1800 stations open $24 \mathrm{~h}$ a day, all year round.

In 2011, the first company offering the fourth-generation Public Bicycle System called A2B Bikeshare was established in the USA. A console powered by built-in solar panels was installed on the bikes. Thanks to it, you can control the rental process and the status of the electric lock. The bicycle's functions have been extended to include GPS tracking, a chip (or proximity) card terminal and a display with information for the borrower, and even with advertising space. The management of the fleet monitored by GPS has also improved the relocation between individual stations.

One of the largest city bike rental services in the world is the German company Nextbike GmbH existing since 2004. One-time registration in the system allows the use of a fleet of 40,000 vehicles across the globe. The system is present, among others, in Germany, Austria, and Switzerland, as well as in Turkey, Cyprus, the United Arab Emirates, Croatia, and Azerbaijan. Nextbike GmbH has also appeared in Latvia, New Zealand, the United States, Great Britain, Bulgaria, and Hungary. The fees are, of course, adapted to local conditions.

Bicycle programs around the world are still undergoing modification. The user identification system is changing and simplifying, but currently uses:

- Mobile telephony

- Credit cards

- City cards

- $\quad$ RFID (Radio-frequency identification) cards [16]

In Poland, the first city bikes appeared in Wrocław in 2011. One of the most popular companies dealing with the Public Bicycle System is Nextbike Polska operating under the Nextbike GmbH mentioned above. It manages, among others, the most extensive Veturilo system in the country, working in Warsaw. In addition to ordinary two-wheelers, you can also rent children's bikes, tandems, and electric bikes in the capital. The area in which you can use Veturilo is very extensive. This is because the Warsaw system is compatible with Konstanciński City Bike, Piaseczyński City Bike, and the KołoMarek system operating since last year in Marki. This means that the vehicle can be returned to each of these cities without any consequences. An additional advantage is one common price list and 20 free minutes at the beginning of each rental.

The condition of using Veturilo is to register on the Veturilo.waw.pl website, through an application or terminal. Then you need to top up your account with at least PLN 10. Then follow the instructions-at the rental station terminal, you have to enter your phone number, PIN, and bike number or use the Veturilo mobile application and scan the bike's QR code. It only takes a few seconds.

The largest and most modern European system providing only electric bicycles is to be the Metropolitan Bicycle created by Nextbike Polska for the Tri-City area. The official start of the entire system is planned for the beginning of March 2019, unfortunately, due to technical reasons, delays have occurred, and further dates of the inauguration are appearing. On 26 March 2019, each commune participating in the project received $30 \%$ of the bikes intended for it (in total, it will be about 1250 units). They are available for rent at each of the 660 stations.

The Tri-City Metropolitan Bicycle will create 4080 electrically assisted bicycles available in 14 communes (Gdańsk, Gdynia, Sopot, Tczew, Pruszcz Gdańsk, Rumia, Reda, Puck, Władysławowo, Żukowo, Kartuzy, Stężyca, Somonino, Sierakowice).

Besides the already mentioned Nextbike Polska company, BikeU and Romet Rental Systems also operate in Poland. The first of them belongs to the French Egis Group, which has its systems in over 100 countries globally. He manages public bicycles in Krakow (Wavelo), Bydgoszcz (BRA), Łomża (ŁoKeR) and Zgierz (Zgierski City Bike) (he once managed systems in Szczecin (Bike_S), Bielsko-Biała (BBbike), and Jastrzębie-Zdrój (Polish Bicycle) BikeU also gives its users free $20 \mathrm{~min}$ at the beginning of each rental and the 
possibility of using all bikes $24 \mathrm{~h}$ a day, seven days a week in the period from the beginning of spring to the end of autumn.

Hiring a city bike shouldn't be a problem for anyone. It is intuitive and lasts a very short time-up to several seconds. Each system offers several ways to rent a bike. This can be done, for example, by using the terminal assigned to the station, using the mobile application on your smartphone, scanning the QR code, or even contactless through the NFC (Near-field communication) module or using a proximity card.

The advantage of the MEVO system is simplicity and an affordable price list. By purchasing a monthly subscription, the user will pay a maximum of PLN 10. He will also get 90 free minutes for journeys every day of the subscription, and after using this limit, he will pay only 5 cents for each additional minute. The annual subscription will be PLN 100, and the time offer and rules will be the same as for the monthly fee. If the user wants to use bicycles without buying a subscription, one minute's cost will be 10 cents. For an additional fee of PLN 3 it will be possible to leave the bike anywhere. However, for returning a bike rented outside the station, the user will receive a PLN 2 bonus.

\subsection{City Scooters}

Electric scooters operating on very similar principles as cars "for minutes" are also interesting and environmentally friendly options. To use them, all you need to do is register in the company's application, be at least 18 years old, have a valid category A driving license, and if you were born before 19 January 1995, you only need your ID card. You must also have a valid payment card from which scooter rental fees will be charged.

Electric scooters "for minutes", just like car-sharing cars, have come to the streets of Polish cities for good. In most cities, they are available from the beginning of March to the end of November, and in the remaining towns throughout the year. You can often find them around the bus and bus stops, tram stops, or near the city rail station.

\section{Influence of New Communication Solutions on the Daily Life of the Agglomeration}

Cars for minutes quickly became part of the cities they came to. Just a short walk to see at least one of these vehicles moving on the street or standing somewhere in the parking lot. The study's main purpose was to illustrate changes in the number of rental cars Traficar and TrafiCargo during the day in the Tri-City agglomeration. They were carried out on 10 May 2020 (Saturday) from 9:00 to 19:00. The study involved collecting data using a mobile application. The availability of vehicles was checked at 15-min intervals. The number of Renault Clio passenger cars and small Renault Kangoo vans was analyzed. The results of the study are shown in the table below (Table 1). The charts show the changes in vehicle availability during the test. To show more accurately the changing number of free passenger vehicles, separate studies have been created for Gdańsk, Gdynia, Sopot, Rumia, and Pruszcz Gdański. Because when scaling the map in the mobile application, the small diagonal of the smartphone screen does not accurately determine the vehicle's location, a measurement error of 5 pieces in a given region was adopted. The most inaccuracies occurred near city borders.

In each of the charts below (Figures 1 and 2), it is seen that from morning hours around 13:30 the number of available vehicles in each of the cities studied changes only slightly (about 10 pieces in hours). This means that most users move within a small area of the car rental area. Much bigger differences in the number of available vehicles can be seen in the afternoon (after 14:00). The later the time, the more vehicles are available in Sopot (Figure 3), where many people arrive on Friday evening to spend the beginning of the weekend. Probably, many of them use car-sharing cars to reach various cultural events and social gatherings. 
Table 1. Availability of TrafiCar and TrafiCargo cars in the Tri-City area on 10 May 2020.

\begin{tabular}{|c|c|c|c|c|c|c|c|c|c|c|}
\hline \multirow{2}{*}{ No. } & \multirow{2}{*}{ Time } & \multirow{2}{*}{$\begin{array}{c}\text { Pruszcz Gdański } \\
\text { TrafiCar }\end{array}$} & \multicolumn{2}{|c|}{ Gdańsk } & \multirow{2}{*}{$\begin{array}{c}\text { Sopot } \\
\text { TrafiCar }\end{array}$} & \multirow{2}{*}{$\begin{array}{c}\text { Gdynia } \\
\text { TrafiCar }\end{array}$} & \multicolumn{2}{|c|}{ Rumia } & \multicolumn{2}{|c|}{ Total } \\
\hline & & & TrafiCar & Trafi Cargo & & & TrafiCar & Trafi Cargo & TrafiCar & Trafi Cargo \\
\hline 1. & 09:02 & 7 & 289 & 7 & 23 & 125 & 19 & 2 & 463 & 9 \\
\hline 2. & 09:17 & 7 & 278 & 7 & 25 & 117 & 19 & 1 & 446 & 8 \\
\hline 3. & 09:30 & 7 & 279 & 7 & 22 & 119 & 19 & 1 & 446 & 8 \\
\hline 4. & 09:45 & 7 & 278 & 7 & 28 & 121 & 20 & 1 & 454 & 8 \\
\hline 5. & 10:03 & 7 & 278 & 4 & 27 & 122 & 20 & 1 & 454 & 5 \\
\hline 6. & 10:15 & 7 & 277 & 4 & 26 & 119 & 21 & 1 & 450 & 5 \\
\hline 7. & 10:30 & 7 & 271 & 3 & 26 & 118 & 26 & 1 & 448 & 4 \\
\hline 8. & $10: 45$ & 7 & 270 & 3 & 25 & 115 & 25 & 1 & 442 & 4 \\
\hline 9. & 11:00 & 7 & 267 & 3 & 25 & 116 & 23 & 1 & 438 & 4 \\
\hline 10. & 11:19 & 7 & 265 & 3 & 26 & 117 & 22 & 1 & 437 & 4 \\
\hline 11. & $11: 30$ & 7 & 259 & 3 & 25 & 112 & 21 & 1 & 424 & 4 \\
\hline 12. & $11: 52$ & 7 & 260 & 4 & 23 & 111 & 21 & 1 & 422 & 5 \\
\hline 13. & $12: 03$ & 7 & 259 & 4 & 25 & 111 & 22 & 1 & 424 & 5 \\
\hline 14. & $12: 15$ & 7 & 265 & 4 & 22 & 114 & 21 & 1 & 429 & 5 \\
\hline 15. & $12: 30$ & 7 & 269 & 2 & 22 & 114 & 22 & 1 & 434 & 3 \\
\hline 16. & $12: 45$ & 7 & 265 & 1 & 21 & 112 & 22 & 1 & 427 & 2 \\
\hline 17. & 13:00 & 6 & 274 & 2 & 18 & 111 & 23 & 1 & 432 & 3 \\
\hline 18. & 13:15 & 4 & 275 & 2 & 19 & 113 & 21 & 1 & 432 & 3 \\
\hline 19. & $13: 30$ & 5 & 275 & 3 & 16 & 115 & 21 & 1 & 432 & 4 \\
\hline 20. & $13: 46$ & 6 & 262 & 3 & 21 & 113 & 20 & 1 & 422 & 4 \\
\hline 21. & $14: 02$ & 5 & 268 & 3 & 24 & 104 & 19 & 1 & 420 & 4 \\
\hline 22. & $14: 21$ & 5 & 268 & 3 & 19 & 102 & 20 & 1 & 414 & 4 \\
\hline 23. & $14: 38$ & 4 & 269 & 3 & 22 & 101 & 27 & 1 & 423 & 4 \\
\hline 24. & $14: 47$ & 3 & 260 & 2 & 22 & 105 & 20 & 1 & 410 & 3 \\
\hline 25. & $15: 01$ & 3 & 252 & 2 & 30 & 102 & 19 & 1 & 406 & 3 \\
\hline 26. & $15: 15$ & 5 & 249 & 2 & 30 & 100 & 19 & 2 & 403 & 4 \\
\hline 27. & $15: 30$ & 6 & 245 & 2 & 31 & 98 & 20 & 3 & 400 & 5 \\
\hline 28. & $15: 45$ & 6 & 241 & 4 & 30 & 99 & 20 & 3 & 396 & 7 \\
\hline 29. & $16: 00$ & 6 & 251 & 6 & 31 & 101 & 19 & 3 & 408 & 9 \\
\hline 30. & $16: 15$ & 6 & 237 & 6 & 32 & 105 & 14 & 3 & 394 & 9 \\
\hline 31. & $16: 35$ & 7 & 235 & 6 & 33 & 97 & 20 & 3 & 392 & 9 \\
\hline 32. & $16: 48$ & 5 & 235 & 5 & 35 & 98 & 21 & 3 & 394 & 8 \\
\hline 33. & $17: 02$ & 7 & 240 & 7 & 26 & 95 & 21 & 3 & 389 & 10 \\
\hline 34. & $17: 17$ & 8 & 226 & 7 & 38 & 96 & 20 & 3 & 388 & 10 \\
\hline 35. & $17: 33$ & 9 & 239 & 7 & 30 & 91 & 19 & 3 & 388 & 10 \\
\hline 36. & $17: 45$ & 7 & 227 & 7 & 36 & 83 & 18 & 3 & 371 & 10 \\
\hline 37. & 18:02 & 8 & 222 & 6 & 38 & 87 & 19 & 3 & 374 & 9 \\
\hline 38. & $18: 17$ & 8 & 222 & 5 & 43 & 86 & 16 & 3 & 375 & 8 \\
\hline 39. & $18: 31$ & 7 & 222 & 5 & 42 & 106 & 16 & 3 & 393 & 8 \\
\hline 40. & $18: 46$ & 8 & 200 & 6 & 52 & 97 & 19 & 3 & 376 & 9 \\
\hline 41. & 19:00 & 8 & 205 & 5 & 49 & 98 & 19 & 3 & 379 & 8 \\
\hline \multicolumn{2}{|c|}{ Total } & 264 & 10,428 & 175 & 1158 & 4366 & 833 & 73 & 17,049 & 248 \\
\hline \multicolumn{2}{|c|}{ Average } & 6.77 & 267.38 & 4.49 & 29.69 & 111.95 & 21.36 & 1.87 & 437.15 & 6.36 \\
\hline
\end{tabular}




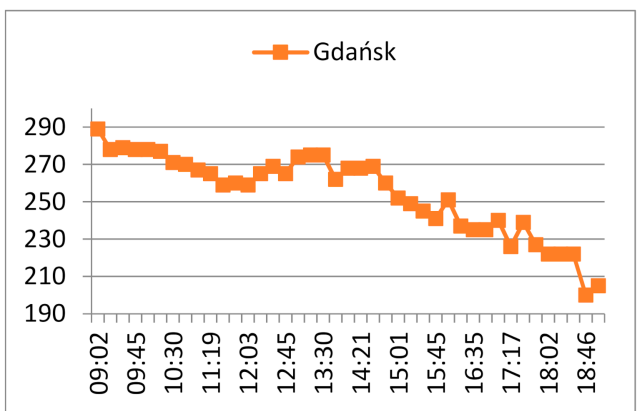

Figure 1. A number of Traficar cars available in the area of Gdańsk. (10 May 2020).

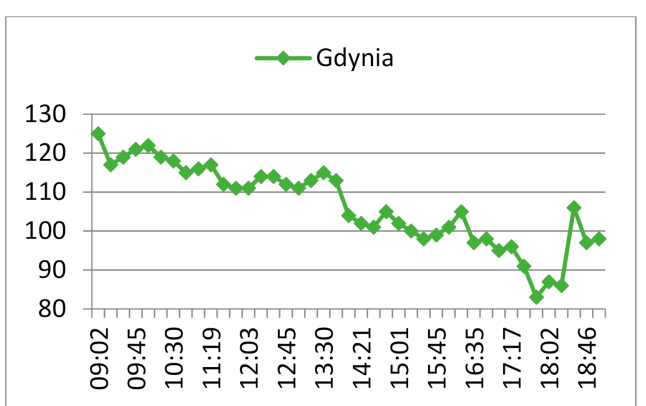

Figure 2. A number of Traficar cars available in the area of Gdynia. (10 May 2020).

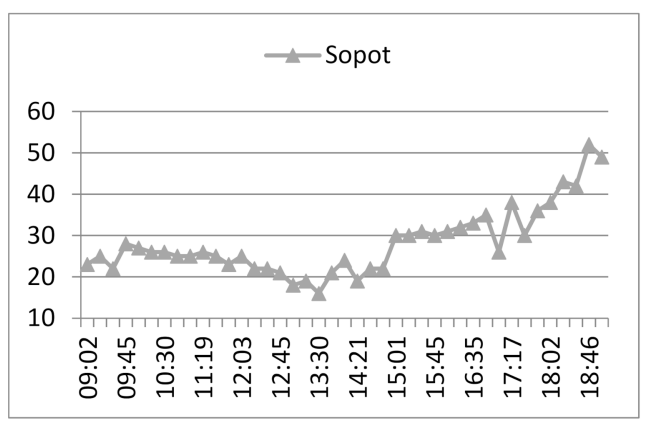

Figure 3. A number of Traficar cars available in the area of Sopot. (10 May 2020).

The chart describing the vehicles available in Sopot (Figure 3) in the initial phase does not differ much from those showing Gdańsk and Gdynia. Around 15:00, the number of vehicles available remains between 20-28, decreasing between 12:30 and 14:02 when 16 cars could be used. From 15:00, there was an increase in the number of cars available, which amounted to a maximum of 52 vehicles at 18:31.

The number of cars available for rent in Pruszcz Gdański (Figure 4) usually stays around 7-8 units. Between 13:00 and 17:00. Probably the cars are used during these hours to reach Gdańsk in order to go shopping or travel to social gatherings.

Because Rumia is close to Gdynia, some vehicles may be incorrectly assigned when the map is too far away in the application. This fact may result in the most visible increases in the chart (Figure 5) and the number of available vehicles. Most of the time, there are 18-22 cars available.

The chart below (Figure 6) presents changes in the number of available Renault Kangoo VAN vans in Gdańsk and Rumia. The first information that can be read from the chart is the lower values of available vehicles between 10:00 and 16:00, i.e., during most people's working hours. A very big advantage of these vehicles is their internal dimensions. The TrafiCargo car's capacity is up to $4.6 \mathrm{~m}^{3}$, and the maximum load capacity is about $800 \mathrm{~kg}$. With the passenger seat folded in, you can get almost $3 \mathrm{~m}$ (exactly $2.89 \mathrm{~m}$ ) 
of usable length with a simultaneous height of $1.13 \mathrm{~m}$ and a width of $1.22 \mathrm{~m}$. With these technical parameters, these cars are ideal for transporting larger construction purchases or smaller furniture.

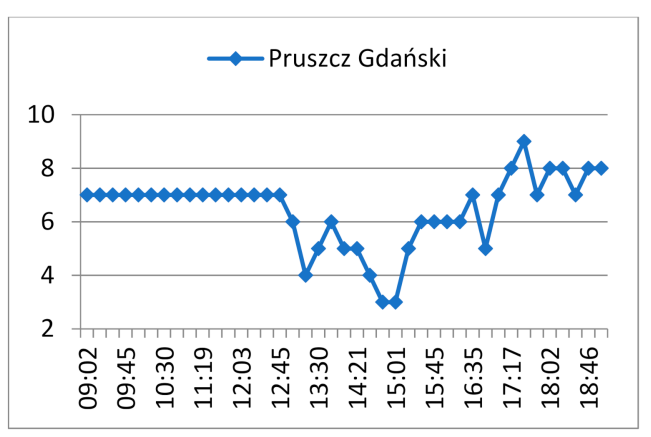

Figure 4. A number of Traficar cars available in the area of Pruszcz Gdański. (10 May 2020).

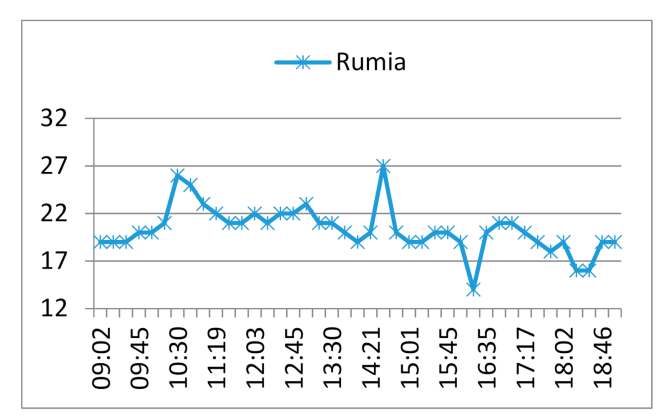

Figure 5. A number of Traficar cars available in the area of Rumia. (10 May 2020).

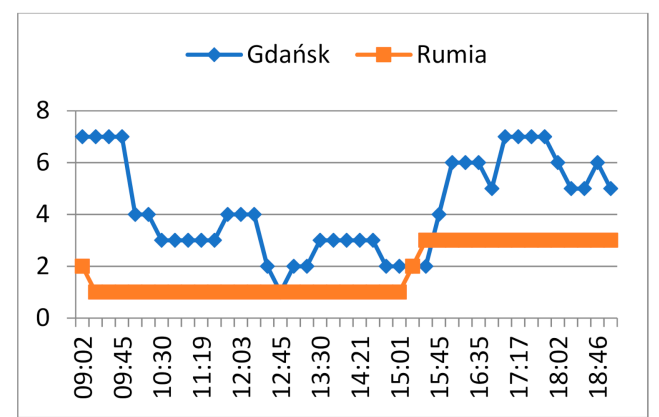

Figure 6. A number of TrafiCargo cars available in Gdańsk and Rumia. (10 May 2020).

On the downside, it should be noted that the start and end of renting are possible only in specially designated areas near known construction stores such as Castorama, IKEA, or Leroy Merlin. This is not very encouraging because it requires additional time to put the vehicle in a dedicated parking lot and later return to the destination.

A single study does not show exact changes in vehicle availability. To compare the differences between a non-working day and a business day, on 12 May 2020 (Tuesday), a re-analysis of the number of vehicles for rent was carried out. The results are given in the Table 2.

On the business day, the differences in vehicle availability were much larger than on the day off. Between individual hours in Gdańsk (Figure 7) and Gdynia (Figure 8), the number of rental cars varies by up to several units. The largest decrease can be observed between 13:00 and 15:00. Later, there is a slight increase, and from 18:00, the available number of vehicles decreases again. 
Table 2. Availability of TrafiCar and TrafiCargo cars in the Tri-City area on 12 May 2020.

\begin{tabular}{|c|c|c|c|c|c|c|c|c|c|c|}
\hline \multirow{2}{*}{ No. } & \multirow{2}{*}{ Time } & \multirow{2}{*}{$\begin{array}{c}\text { Pruszcz Gdański } \\
\text { TrafiCar }\end{array}$} & \multicolumn{2}{|c|}{ Gdańsk } & \multirow{2}{*}{$\begin{array}{c}\text { Sopot } \\
\text { TrafiCar }\end{array}$} & \multirow{2}{*}{$\begin{array}{c}\text { Gdynia } \\
\text { TrafiCar }\end{array}$} & \multicolumn{2}{|c|}{ Rumia } & \multicolumn{2}{|c|}{ Total } \\
\hline & & & TrafiCar & Trafi Cargo & & & TrafiCar & Trafi Cargo & TrafiCar & Trafi Cargo \\
\hline 1. & 07:04 & 10 & 234 & 12 & 52 & 102 & 25 & 3 & 423 & 15 \\
\hline 2. & $07: 15$ & 11 & 230 & 12 & 51 & 103 & 24 & 3 & 419 & 15 \\
\hline 3. & 07:31 & 11 & 225 & 12 & 51 & 103 & 23 & 3 & 413 & 15 \\
\hline 4. & $07: 46$ & 11 & 226 & 12 & 49 & 101 & 23 & 3 & 410 & 15 \\
\hline 5. & 08:00 & 10 & 226 & 12 & 51 & 101 & 23 & 3 & 411 & 15 \\
\hline 6. & 08:15 & 10 & 222 & 12 & 57 & 100 & 24 & 3 & 413 & 15 \\
\hline 7. & $08: 29$ & 9 & 209 & 12 & 58 & 102 & 24 & 3 & 402 & 15 \\
\hline 8. & 08:44 & 10 & 208 & 12 & 57 & 101 & 23 & 3 & 399 & 15 \\
\hline 9. & 09:01 & 12 & 222 & 12 & 58 & 107 & 22 & 3 & 421 & 15 \\
\hline 10. & 09:16 & 10 & 227 & 12 & 54 & 105 & 22 & 3 & 418 & 15 \\
\hline 11. & 09:30 & 11 & 223 & 12 & 58 & 109 & 24 & 3 & 425 & 15 \\
\hline 12. & 09:47 & 11 & 227 & 12 & 55 & 108 & 24 & 3 & 425 & 15 \\
\hline 13. & $10: 00$ & 11 & 232 & 10 & 59 & 108 & 24 & 3 & 434 & 13 \\
\hline 14. & $10: 15$ & 11 & 236 & 10 & 55 & 106 & 25 & 3 & 433 & 13 \\
\hline 15. & $10: 33$ & 11 & 228 & 10 & 51 & 107 & 24 & 3 & 421 & 13 \\
\hline 16. & $10: 48$ & 11 & 237 & 11 & 58 & 106 & 23 & 2 & 435 & 13 \\
\hline 17. & $11: 00$ & 11 & 241 & 11 & 59 & 108 & 22 & 2 & 441 & 13 \\
\hline 18. & $11: 18$ & 8 & 233 & 11 & 56 & 104 & 22 & 2 & 423 & 13 \\
\hline 19. & $11: 31$ & 9 & 236 & 11 & 58 & 101 & 22 & 2 & 426 & 13 \\
\hline 20. & $11: 46$ & 8 & 234 & 11 & 55 & 109 & 24 & 2 & 430 & 13 \\
\hline 21. & $12: 00$ & 9 & 236 & 11 & 56 & 112 & 23 & 2 & 436 & 13 \\
\hline 22. & $12: 15$ & 8 & 242 & 11 & 47 & 104 & 25 & 2 & 426 & 13 \\
\hline 23. & $12: 30$ & 8 & 232 & 11 & 53 & 108 & 25 & 2 & 426 & 13 \\
\hline 24. & $12: 49$ & 8 & 234 & 11 & 58 & 106 & 25 & 2 & 431 & 13 \\
\hline 25. & $13: 02$ & 9 & 223 & 11 & 58 & 105 & 24 & 2 & 419 & 13 \\
\hline 26. & $13: 15$ & 8 & 224 & 11 & 57 & 105 & 23 & 2 & 417 & 13 \\
\hline 27. & $13: 31$ & 10 & 220 & 11 & 61 & 98 & 23 & 2 & 412 & 13 \\
\hline 28. & $13: 45$ & 10 & 224 & 11 & 64 & 98 & 23 & 3 & 419 & 14 \\
\hline 29. & $14: 00$ & 10 & 220 & 11 & 61 & 99 & 22 & 3 & 412 & 14 \\
\hline 30. & $14: 15$ & 10 & 212 & 11 & 62 & 98 & 21 & 3 & 403 & 14 \\
\hline 31. & $14: 30$ & 11 & 210 & 11 & 65 & 94 & 24 & 3 & 404 & 14 \\
\hline 32. & $14: 45$ & 9 & 213 & 11 & 58 & 100 & 23 & 3 & 403 & 14 \\
\hline 33. & $15: 00$ & 9 & 211 & 11 & 59 & 103 & 22 & 3 & 404 & 14 \\
\hline 34. & $15: 15$ & 8 & 202 & 10 & 59 & 103 & 23 & 3 & 395 & 13 \\
\hline 35. & $15: 30$ & 8 & 197 & 10 & 54 & 102 & 22 & 3 & 383 & 13 \\
\hline 36. & $15: 45$ & 9 & 199 & 10 & 54 & 110 & 22 & 3 & 394 & 13 \\
\hline 37. & $16: 00$ & 8 & 204 & 10 & 53 & 109 & 20 & 3 & 394 & 13 \\
\hline 38. & $16: 16$ & 8 & 199 & 12 & 55 & 108 & 20 & 3 & 390 & 15 \\
\hline 39. & $16: 30$ & 9 & 219 & 12 & 34 & 103 & 20 & 3 & 385 & 15 \\
\hline 40. & $16: 45$ & 7 & 220 & 12 & 33 & 103 & 22 & 3 & 385 & 15 \\
\hline 41. & $17: 00$ & 9 & 225 & 12 & 30 & 105 & 24 & 3 & 393 & 15 \\
\hline 42. & $17: 19$ & 8 & 237 & 13 & 29 & 103 & 24 & 3 & 401 & 16 \\
\hline 43. & $17: 31$ & 8 & 229 & 13 & 27 & 104 & 23 & 3 & 391 & 16 \\
\hline 44. & $17: 45$ & 8 & 228 & 13 & 25 & 100 & 22 & 3 & 383 & 16 \\
\hline 45. & $18: 00$ & 9 & 220 & 12 & 39 & 112 & 23 & 3 & 403 & 15 \\
\hline 46. & $18: 19$ & 9 & 214 & 12 & 44 & 108 & 20 & 3 & 395 & 15 \\
\hline 47. & $18: 30$ & 8 & 205 & 12 & 37 & 105 & 21 & 3 & 376 & 15 \\
\hline 48. & $18: 45$ & 7 & 201 & 11 & 36 & 103 & 20 & 3 & 367 & 14 \\
\hline 49. & 19:04 & 6 & 200 & 12 & 37 & 101 & 20 & 3 & 364 & 15 \\
\hline \multicolumn{2}{|c|}{ Total } & 372 & 9076 & 462 & 2081 & 4287 & 927 & 111 & 16,743 & 573 \\
\hline \multicolumn{2}{|c|}{ Average } & 9.54 & 232.72 & 11.85 & 53.36 & 109.92 & 23.77 & 2.85 & 429.31 & 14.69 \\
\hline
\end{tabular}




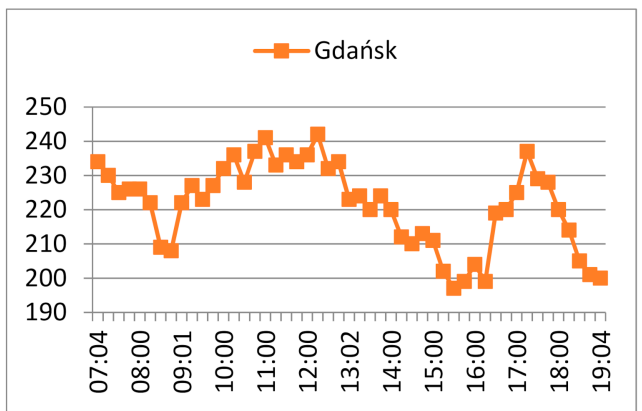

Figure 7. A number of Traficar cars available in the area of Gdańsk. 12 May 2020.

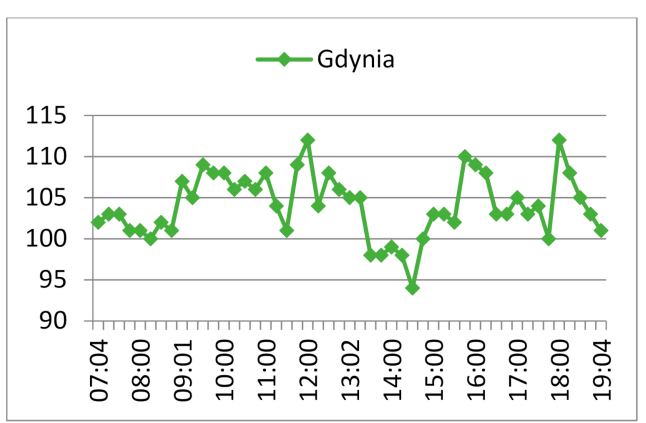

Figure 8. A number of Traficar cars available in the area of Gdynia. 12 May 2020.

In Sopot (Figure 9), most of the day, there is a relatively constant number of vehicles in the number of 50-60 units. A small increase in available cars can be seen between 13:30 and 15:00. At 16:30, a sudden drop to 34 cars continued until 18:00 when 24 vehicles were available.

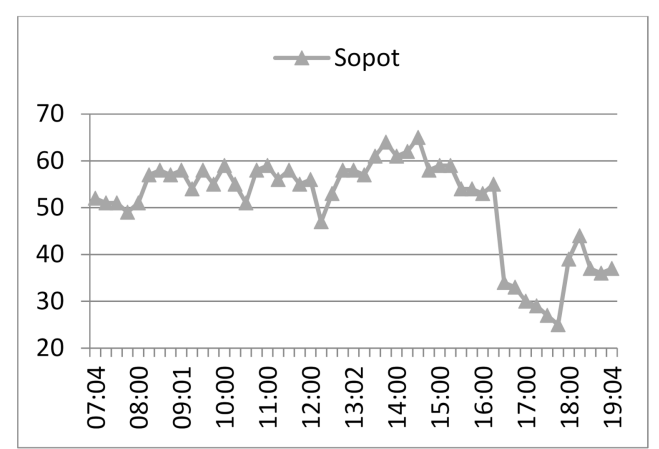

Figure 9. A number of Traficar cars available in the area of Sopot. 12 May 2020.

In the morning in Pruszcz Gdański (Figure 10), 9-12 are available. This situation lasts around 11:00. For the next 2 h, 8-9 vehicles are available. From 13:30 to 14:30, there are ten cars available, and you can use 8-9 vehicles again.

The difference in vehicle availability between studies shows a decrease in disused vehicles. (compare Tables 1 and 2 with Table 3) It is visible, especially in the mean value. With the overall number of cars being very similar in both studies, the decline in availability indicates more generous use of shared vehicles by society. The increasing awareness of city dwellers about using other moving methods around the city has a large share in this. Of course, such research should be repeated cyclically, taking into account also other companies that also appeared on the market of vehicle rental services in the analyzed period. A separate topic worth exploring is also the rental of long-term vehicles. There is also a noticeable trend of car rentals for holiday rest for wider and wider society.5. Innovative solutions applied in the Tri-City. 


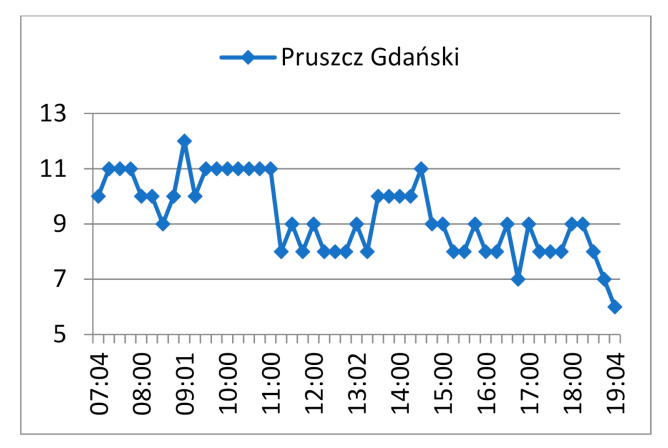

Figure 10. A number of Traficar cars available in the area of Pruszcz Gdański. 12 May 2020.

Table 3. Availability of TrafiCar and TrafiCargo cars in the Tri-City area on 17 November 2020.

\begin{tabular}{|c|c|c|c|c|c|c|c|c|c|c|}
\hline \multirow{2}{*}{ No. } & \multirow{2}{*}{ Time } & \multirow{2}{*}{$\begin{array}{c}\text { Pruszcz Gdański } \\
\text { TrafiCar }\end{array}$} & \multicolumn{2}{|c|}{ Gdańsk } & \multirow{2}{*}{$\begin{array}{c}\text { Sopot } \\
\text { TrafiCar }\end{array}$} & \multirow{2}{*}{$\begin{array}{c}\text { Gdynia } \\
\text { TrafiCar }\end{array}$} & \multicolumn{2}{|c|}{ Rumia } & \multicolumn{2}{|c|}{ Total } \\
\hline & & & TrafiCar & Trafi Cargo & & & TrafiCar & Trafi Cargo & TrafiCar & Trafi Cargo \\
\hline 1. & 09:14 & 9 & 174 & 9 & 38 & 83 & 19 & 0 & 347 & 10 \\
\hline 2. & $09: 24$ & 9 & 158 & 10 & 46 & 86 & 21 & 1 & 299 & 8 \\
\hline 3. & 09:41 & 6 & 168 & 9 & 43 & 84 & 21 & 2 & 314 & 8 \\
\hline 4. & 09:56 & 9 & 180 & 10 & 37 & 82 & 18 & 1 & 340 & 10 \\
\hline 5. & $10: 08$ & 9 & 152 & 9 & 38 & 82 & 17 & 2 & 345 & 10 \\
\hline 6. & $10: 23$ & 6 & 163 & 10 & 41 & 87 & 18 & 2 & 332 & 11 \\
\hline 7. & $10: 39$ & 5 & 163 & 9 & 46 & 93 & 20 & 2 & 307 & 10 \\
\hline 8. & $10: 52$ & 9 & 168 & 7 & 39 & 87 & 18 & 1 & 327 & 7 \\
\hline 9. & $11: 11$ & 6 & 180 & 9 & 42 & 87 & 17 & 2 & 298 & 9 \\
\hline 10. & $11: 26$ & 7 & 156 & 8 & 31 & 83 & 21 & 1 & 309 & 8 \\
\hline 11. & $11: 40$ & 7 & 152 & 8 & 38 & 88 & 21 & 0 & 318 & 9 \\
\hline 12. & $11: 57$ & 8 & 169 & 8 & 41 & 87 & 21 & 2 & 297 & 7 \\
\hline 13. & $12: 08$ & 9 & 176 & 10 & 31 & 89 & 17 & 0 & 336 & 8 \\
\hline 14. & $12: 24$ & 4 & 179 & 7 & 37 & 81 & 17 & 2 & 350 & 11 \\
\hline 15. & $12: 43$ & 6 & 156 & 9 & 40 & 91 & 19 & 1 & 344 & 7 \\
\hline 16. & $12: 56$ & 7 & 167 & 9 & 36 & 82 & 19 & 0 & 330 & 9 \\
\hline 17. & $13: 08$ & 5 & 150 & 10 & 40 & 83 & 18 & 0 & 321 & 9 \\
\hline 18. & $13: 27$ & 6 & 163 & 9 & 31 & 80 & 17 & 1 & 310 & 10 \\
\hline 19. & $13: 39$ & 9 & 167 & 7 & 40 & 91 & 20 & 2 & 307 & 11 \\
\hline 20. & $13: 54$ & 6 & 151 & 8 & 30 & 91 & 17 & 0 & 340 & 10 \\
\hline 21. & 14:09 & 4 & 155 & 8 & 41 & 89 & 17 & 0 & 324 & 9 \\
\hline 22. & $14: 23$ & 7 & 177 & 8 & 38 & 79 & 20 & 1 & 349 & 11 \\
\hline 23. & $14: 40$ & 5 & 157 & 7 & 46 & 90 & 18 & 2 & 313 & 8 \\
\hline 24. & $14: 59$ & 5 & 180 & 8 & 47 & 92 & 18 & 1 & 295 & 11 \\
\hline 25. & $15: 12$ & 4 & 162 & 7 & 38 & 89 & 18 & 0 & 346 & 7 \\
\hline 26. & $15: 24$ & 9 & 160 & 8 & 44 & 82 & 19 & 1 & 322 & 8 \\
\hline 27. & $15: 41$ & 5 & 165 & 9 & 36 & 89 & 21 & 0 & 293 & 7 \\
\hline 28. & $15: 53$ & 6 & 168 & 7 & 44 & 83 & 19 & 1 & 336 & 7 \\
\hline 29. & $16: 09$ & 5 & 157 & 10 & 34 & 82 & 21 & 0 & 290 & 11 \\
\hline 30. & $16: 23$ & 4 & 160 & 9 & 32 & 82 & 18 & 0 & 335 & 8 \\
\hline \multicolumn{2}{|c|}{ Total } & 372 & 9076 & 462 & 2081 & 4287 & 927 & 111 & 16,743 & 573 \\
\hline \multicolumn{2}{|c|}{ Average } & 9.54 & 232.72 & 11.85 & 53.36 & 109.92 & 23.77 & 2.85 & 429.31 & 14.69 \\
\hline
\end{tabular}


A year and a half after Traficar makes car-sharing services available in the Tri-City, it can be said that cars "for minutes" have permanently entered the Tri-City landscape. The car-sharing service and other innovative communication solutions, introduced more and more often in recent years, are quickly gaining recognition among the inhabitants of large cities, especially among young people who are open to new technologies and solutions. Moving the Tri-City cannot miss at least a few standing in the parking lot or moving vehicles through the streets of Traficar-distinctive silver Renault cars with purple lettering and LEDs daytime running lights. The fleet available in the Tri-City is 500 cars.

People often use car-sharing cars to get to work, university, or social gatherings. Companies providing this service are continually expanding their activities and fleets in response to users' growing interested and demand. There is also a competition. Shortly after the success of Traficar, the CityBee company appeared on the market, offering the rental of large vans such as Fiat Ducato or Volkswagen Crafter. However, in mid-February 2019, MiiMove began operating, offering 200 fifth-generation Opel Astra Hatchback cars with automatic transmission.

The variety of types of vehicles available for rent very favorably supports companies' competitiveness and motivates further development and introduction of newer and newer solutions.

Traficar is the right solution for extensive family shopping. Even if a store (e.g., Biedronka, Lidl, or a regular local grocery store) is nearby, transporting products is a problem with larger purchases. Traficar vehicles are also great for small removals: with a folded rear sofa, you can fit even a dozen cardboard boxes inside.

The cost of a single trip when using car-sharing services is much more favorable than a trip ordered by taxi and comparable to UBER trips. Sometimes it is also competitive with public transport prices. For example, a course from the Maritime University building in Gdynia located at Morska Street to the Faculty of Navigation of that university at Kościuszki Square costs about PLN 8. If there are five people in the car, each passenger and driver will pay about the equivalent of a one-off reduced-price public transport ticket for the same journey (the cost of such a ticket is PLN 1.60).

Traficar also works well as a fast and convenient means of transport during the public transport summit, in bad weather or late hours, when public transport runs very rarely.

On the plus side, you can save a well-functioning mobile application that allows you to track available vehicles nearby and even set up a special scanner, informing the user if a car appears in the designated area within a specified time, which he can use. An interesting solution is additional minutes for the driver ( 2 in the spring and summer and 5 in the autumn and winter, thanks to which he can calmly prepare for driving (setting the seat and mirrors and checking the vehicle's condition) without incurring additional costs. Noteworthy is also an efficient notification system, which informs users regularly about any changes made to the service or about updates, system interruptions, and curiosities.

When booking a vehicle, the user is usually located at a distance from the vehicle and, therefore, unable to check its condition in advance. Only the approximate amount of fuel is visible in the application. After reaching the car, it may turn out that the previous user left a considerable disorder inside. The vehicle is damaged or has been parked incorrectly. A blockade has been placed by the city guard and a ticket issued. You should then call the helpline, which works very efficiently, and all problems and information are immediately transferred to technical teams who take cars to the car wash, clean them and replenish any missing operating fluids and refuel vehicles.

Most car-sharing services providers in Poland do not have a specific price offer for renting a vehicle for a more extended period (all day, week, month, or year).

The rates for all car-sharing operators are very similar, which maintains a balance among competitors. Like MiiMove, some, fighting for each customer, go a step further and offer, for example, a reduced rate for parking between 22:00-7:00, when there are the least active users. 
On 17 December 2018, Traficar launched a new service for its users-intercity journeys. It allows you to start renting a Traficar passenger car in one city and ending in another. It applies between agglomeration zones in which you can use the company's services, i.e., in Krakow, Warsaw, the Tri-City, Wroclaw, and Silesia. A new fee has also been introduced-the "daily rate", which is only applicable when traveling from one agglomeration to another. It is $24 \mathrm{~h}$ counted from the start of the rental. Works only when the sum of driving and stopping time is up to PLN 75/day. After exceeding this amount, calculated for renting and parking, only a kilometer fee is charged. After $24 \mathrm{~h}$, the day is counted again. Users traveling on the motorway must pay for it themselves.

MiiMove has offered a similar service since the beginning of its operation. However, the daily rate is higher than when using Traficar-here it is PLN 100 per day of renting (the maximum cost of driving and stopping time) with the standard charging of kilometers. The difference is also in the meaning of the day-here, it applies from midnight one day to midnight the next day. As the company operates only in the Tri-City, this rate applies to normal vehicle use throughout the day.

When introducing intercity journeys, Traficar also launched the so-called safe-driving service. It involves assessing the driving style of drivers. The overall assessment is influenced by three components: speed, braking, and driving technique. MiiMove users are rated very similarly. The only difference is the greater number of components.

The appearance of mobile applications (Figures 11 and 12), thanks to which you can book a vehicle, and after reaching its parking place-open it, it does not differ much.

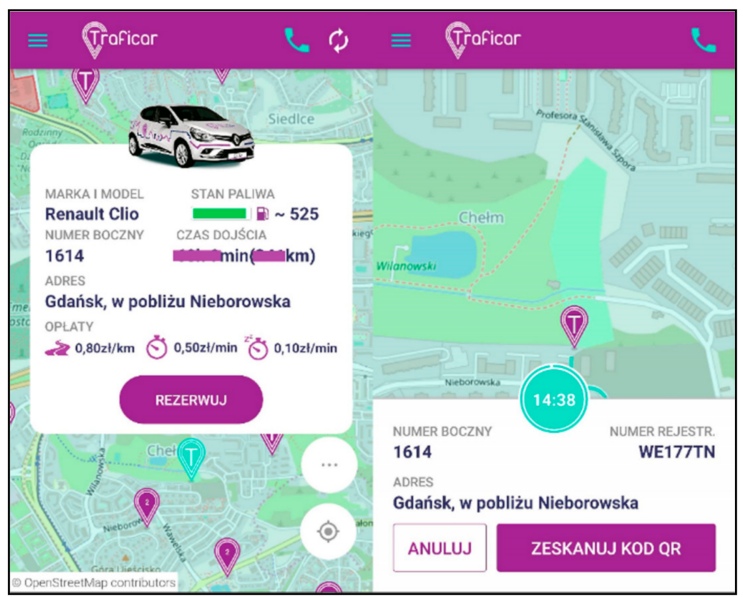

Figure 11. Traficar-reservation screen (before and during).

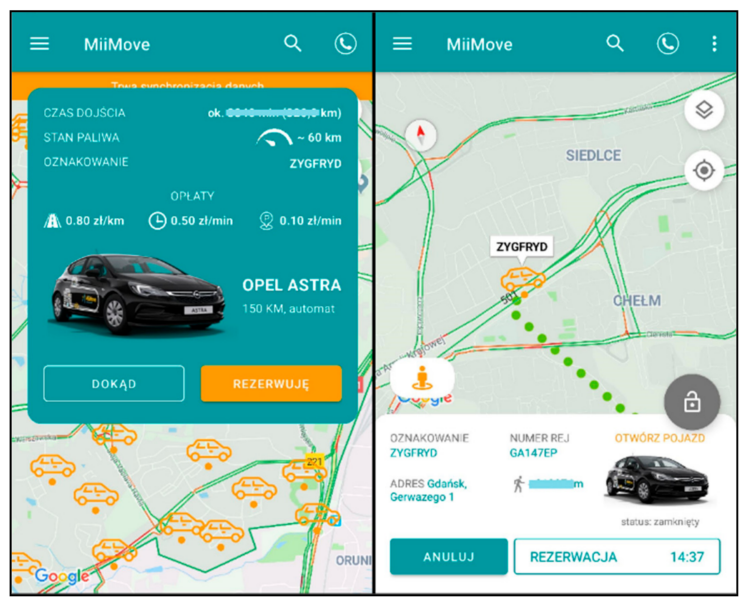

Figure 12. MiiMove-reservation screen (before and during). 
The advantage of the Traficar application is the grouping of vehicles from one area while moving the map away - this increases readability. This is much less readable with competitors. Moreover, Traficar instantly zooms the map to the user's current location. In the MiiMove application, you have to do it manually.

The owner of the largest fleet of cars made available on a car-sharing basis-Traficar is expanding its offer and directs it to private customers and companies that are looking for savings even in terms of business trips. In the age of virtual communication, professional meetings take place less frequently than in the past, so entrepreneurs can reduce cars. To them, Traficar offers a fleet sharing service, i.e., the car rental for companies for minutes.

The Chief Operating Officer of Traficar explains the innovation of their proposals for companies: In Polish companies, the scheme prevails, in which 20 employees use the fleet of 20 company cars. However, they only use vehicles on certain days. We offer eight such cars to employees in the booking system. Cars stand under the office, and anyone can reserve a vehicle in the application when they need it. This number of vehicles will meet more employees' needs than when most cars are useless during working hours.

Cars are ordered via the Traficar mobile application. This saves time previously spent by the company on fleet service. Other benefits include automatic settlement of payments for parking in the zone, fleet panel, a fuel card, service.

Traficar, based on many years of experience, differentiates offers for companies. He also said: We offer entrepreneurs various variants of using our vehicles in the fleet sharing service. We have over 20 years of experience in the vehicle rental market, and we know what requirements this new business area sets for us. We leave with an alternative to servicing the fleet of company cars, and automatic parking settlement or servicing on our side are additional elements that increase a company's savings using this formula.

The service is available in three variants:

- Carsharing for companies where employees can use the entire fleet of Traficara cars receives one summary settlement.

- Fleetsharing for companies when employees have access to cars reserved exclusively for the client's company.

- Fleetsharing for companies in which an offer tailored to their individual needs is created on request.

Facilitations prepared by Traficar include many interesting facilities regarding financial settlements with companies using fleet sharing. Among them, one must first of all, calculate:

- Bank account, to which you can connect any number of employees, thanks to which the employer has constant monitoring of all business trips in the fleet panel, and his employees' reserve vehicles in advance in the application (calendar function).

- A fleet card, thanks to which the employee regulates payments for refueling, washing, and traveling on toll road sections.

- Automatic settlement of charges for parking lots in paid zones in the case of the variant with an exclusive fleet.

- $\quad$ Servicing of vehicles separated for companies at night by Traficar employees.

- Issuing a collective invoice with billing at the end of each month in each service OPTION.

- $\quad 24 / 7$ customer helpline.

The new Traficar service is economical, comfortable, and modern, and above all meets the needs of the Polish market. A similar service is offered in the offer of MiiMove and CityBee, introduced in mid-February 2019, providing commercial vehicles with 3.5 tons GVW (Gross vehicle weight).

\section{Summary and Conclusions}

People who decide, because of their functions and professions, about the future of cities must change their philosophy of thinking to not make mistakes that will take revenge on future generations. Each innovative transport solution has a positive effect 
on reducing congestion on the streets, protecting the environment, and taking care of city dwellers' health, both small and large megapolis. There is also a growing awareness of the negative effects of using your car in the city every day. It is emphasized how much evil caused minimal physical effort and how easily this adverse phenomenon can be reversed, encouraging people to give up moving by private cars for cycling, walking, and using public transport.

Innovative solutions should aim to reduce the number of cars in the city. This will affect residents' safety and reverse the trend of escaping to the suburbs that have been going on for years. When the pace of life in large urban centers slows down, people will have time to restore normal good relationships and willingness to act to benefit local communities. Fewer cars mean more bike paths and pavements, children's playgrounds, parks.

However, these positive phenomena will not appear automatically. They require the systematic creation of acceptable practices, large-scale education, and promotional activities. City residents should learn about the results of studies and analyzes that show the benefits of car sharing, using city bikes, creating free zones, or significantly reducing speed for their health, quality of life, and the environment. Concepts such as sustainable development or calmed traffic zones should become close to all local governments or logistics specialists and every average policy resident.

People are open to everything that improves their quality of life, so you need to make modern information and communication technologies serve man on creating happy cities.

The paper presents a short-term rental history and analyzes how many and which companies have appeared in this industry. Car rentals were analyzed. On this basis, it was concluded that such rental would be more and more popular. From the moment of the analysis, another company providing such services has appeared in the Tri-City market, which, in my opinion, makes the trend of sustainable transport development presented in the article more credible.

The detailed analysis made confirms the preliminary observations. The quality of life of the society in the agglomeration is improving. Despite the increasing number of private vehicles, rentals are doing quite well. The developing market proves that it is no longer enough to have but to be able to drive a car, especially in the streets of crowded cities.

Funding: This study was funded by the Gdynia Maritime University, the research project: WN/2020/ PZ/01.

Data Availability Statement: Publicly available datasets were analyzed in this study. This data can be found here: https:/ / www.traficar.pl/.

Conflicts of Interest: The author declares no conflict of interest.

\section{References}

1. Tundys, B. Logistyka Miejska. Teoria i Praktyka; Difin: Warsaw, Poland, 2013; ISBN 9788379300587.

2. Deloitte Tohmatsu LLC. Car Sharing in Europe-Business Models, National Variations, and Upcoming Disruptions. Available online: https:/ / www2.deloitte.com/uk/en/pages/manufacturing/articles/car-sharing-in-europe.html (accessed on 3 December 2020).

3. Przybylowski, A.; Stelmak, S.; Suchanek, M. Mobility Behaviour in View of the Impact of the COVID-19 Pandemic-Public Transport Users in Gdansk Case Study. Sustainability 2021, 13, 364. [CrossRef]

4. $\quad$ Łukasik, Z.; Kuśmińska-Fijałkowska, A.; Kozyra, J.; Olszańska, S. Consolidation of Cargos in the Road Transport as a Key Method to Success. Commun. Sci. Lett. Univ. Zilina 2020, 23, A54-A61. [CrossRef]

5. Statistics Poland (GUS). Available online: https://bdl.stat.gov.pl/BDL/start (accessed on 5 January 2021).

6. Lisbon Charter, International Water Association. 2015. Available online: https://iwa-network.org/wp-content/uploads/2015/1 2/1428790487-Lisbon_Regulators_Charter.pdf (accessed on 5 December 2020).

7. Neumann, T. The Importance of Telematics in the Transport System. Transnav Int. J. Mar. Navig. Saf. Sea Transp. 2018, 12, 617-623. [CrossRef]

8. Agatz, N.A.H.; Erera, A.L.; Savelsbergh, M.W.P.; Wang, X. Optimization for dynamic ride-sharing: A review. Eur. J. Oper. Res. 2012, 223, 295-303. [CrossRef]

9. Banach, M. Od Inteligentnego Transportu Do Inteligentnych Miast; PWN: Warsaw, Poland, 2020; ISBN 9788301201029.

10. Kwon, Y. A Review on the National Culture and Its Effects on the Transportation Safety Perspectives. Transnav Int. J. Mar. Navig. Saf. Sea Transp. 2019, 13, 275-281. [CrossRef] 
11. Keller, A.; Aguilar, A.; Hanss, D. Car Sharers' Interest in Integrated Multimodal Mobility Platforms: A Diffusion of Innovations Perspective. Sustainability 2018, 10, 4689. [CrossRef]

12. Leipzig Charter on Sustainable European Cities. 2007. Available online: https://ec.europa.eu/regional_policy/archive/themes/ urban/leipzig_charter.pdf (accessed on 5 January 2021).

13. Akyelken, N.; Banister, D.; Givoni, M. The Sustainability of Shared Mobility in London: The Dilemma for Governance. Sustainability 2018, 10, 420. [CrossRef]

14. Li, W.; Kamargianni, M. Steering short-term demand for car-sharing: A mode choice and policy impact analysis by trip distance. Transportation 2019, 47, 1-33. [CrossRef]

15. Guze, S. Graph Theory Approach to the Vulnerability of Transportation Networks. Algorithms 2019, 12, 270. [CrossRef]

16. Choromański, W. Systemy Transportowe PRT; WKL: Warsaw, Poland, 2015; ISBN 9788320619553.

17. Nuortio, T.; Kytojoki, J.; Niska, H.; Braysy, O. Improved route planning and scheduling of waste collection and transport. Expert Syst. Appl. 2006, 30, 223-232. [CrossRef]

18. Neumann, T. Routing Planning as an Application of Graph Theory with Fuzzy Logic. Transnav Int. J. Mar. Navig. Saf. Sea Transp. 2016, 10, 661-664. [CrossRef]

19. Neumann, T. Automotive and telematics transportation systems. In Proceedings of the 2017 International Siberian Conference on Control and Communications (SIBCON), Astana, Kazakhstan, 29-30 June 2017; pp. 1-4.

20. Neumann, T. Telematic Support in Improving Safety of Maritime Transport. Transnav Int. J. Mar. Navig. Saf. Sea Transp. 2018, 12, 231-235. [CrossRef]

21. Wyszomirski, O. Transport Miejski. Ekonomika i Organizacja; University of Gdańsk: Gdańsk, Poland, $2010 ;$ ISBN 9788373265073.

22. Acheampong, R.A.; Siiba, A. Modelling the determinants of car-sharing adoption intentions among young adults: The role of attitude, perceived benefits, travel expectations and socio-demographic factors. Transportation 2019, 47, 2557-2580. [CrossRef]

23. Wang, F.; Zhu, Y.; Wang, F.; Liu, J.; Ma, X.; Fan, X. Car4Pac: Last Mile Parcel Delivery Through Intelligent Car Trip Sharing. IEEE Trans. Intell. Transp. Syst. 2020, 21, 4410-4424. [CrossRef]

24. Longhi, L.; Nanni, M. Car telematics big data analytics for insurance and innovative mobility services. J. Ambient. Intell. Humaniz. Comput. 2020, 11, 3989-3999. [CrossRef]

25. Neumann, T. Wykorzystanie Systemów Telematyki Na Przykładzie Wybranych Przedsiębiorstw Transportu Drogowego. Autobusy: Tech. Eksploat. Syst. Transp. 2017, 18, 605-610.

26. Levinger, C.; Hazon, N.; Azaria, A. Human satisfaction as the ultimate goal in ridesharing. Future Gener. Comput. Syst. 2020, 112, 176-184. [CrossRef]

27. Vilke, S.; Brčic, D.; Kos, S. Northern and Southern European Traffic Flow Land Segment Analysis as Part of the Redirection Justification. Transnav Int. J. Mar. Navig. Saf. Sea Transp. 2017, 11, 673-679. [CrossRef]

28. Picasso, E.; Postorino, M.N.; Bonoli-Escobar, M.; Stewart-Harris, M. Car-sharing vs. bike-sharing: A choice experiment to understand young people behaviour. Transp. Policy 2020, 97, 121-128. [CrossRef]

29. Walker, P. How Cycling Can Save the World; Penguin Books: New York, NY, USA, 2017; ISBN 9780143111771.

30. Gariazzo, C.; Pelliccioni, A.; Bogliolo, M.P. Spatiotemporal Analysis of Urban Mobility Using Aggregate Mobile Phone Derived Presence and Demographic Data: A Case Study in the City of Rome, Italy. Data 2019, 4, 8. [CrossRef]

31. Medina-Tapia, M.; Robusté, F. Implementation of Connected and Autonomous Vehicles in Cities Could Have Neutral Effects on the Total Travel Time Costs: Modeling and Analysis for a Circular City. Sustainability 2019, 11, 482. [CrossRef]

32. Miej Auto Bez Auta. O Co Chodzi w Miejskim Carsharingu? Available online: https://wethecrowd.pl/miejski-carsharing (accessed on 10 December 2020).

33. TrafiCar. Available online: https:/ / www.traficar.pl/ (accessed on 10 December 2020).

34. Łebkowski, A. Studies of Energy Consumption by a City Bus Powered by a Hybrid Energy Storage System in Variable Road Conditions. Energies 2019, 12, 951. [CrossRef]

35. Guidotti, R.; Nanni, M.; Rinzivillo, S.; Pedreschi, D.; Giannotti, F. Never drive alone: Boosting carpooling with network analysis. Inf. Syst. 2017, 64, 237-257. [CrossRef]

36. Berlingerio, M.; Ghaddar, B.; Guidotti, R.; Pascale, A.; Sassi, A. The GRAAL of carpooling: GReen And sociAL optimization from crowd-sourced data. Transp. Res. Part C Emerg. Technol. 2017, 80, 20-36. [CrossRef]

37. Carpool24. Available online: http://www.carpool24.pl (accessed on 10 December 2020).

38. Blablacar. Available online: http:/ / www.blablacar.pl (accessed on 10 December 2020).

39. Bełch, P. Carpooling—Narzędzie Redukcji Natężenia Kongestii Transportowej w Mieście. Logistyka 2014 , 3, 466-473. 